\title{
PENGARUH BRAND IMAGE TERHADAP WORD OF MOUTH YANG DIMEDIASI OLEH CUSTOMER SATISFACTION
}

\author{
Putu Yuke Prabandari Erawan 1 \\ I G N Jaya Agung Widagda $\mathrm{K}^{2}$ \\ ${ }^{1,2}$ Fakultas Ekonomi dan Bisnis Universitas Udayana (Unud), Bali, Indonesia \\ email: prabandari_yuke@yahoo.co.id
}

\begin{abstract}
ABSTRAK
WOM adalah bentuk komunikasi interpersonal diantara konsumen tentang pengalaman pribadi dengan produk atau perusahaan. survei pendahuluan yang dilakukan terhadap 20 orang konsumen yang pernah berbelanja di Miniso, diperoleh hasil bahwa 18 konsumen pernah melakukan promosi word of mouth. Penelitian ini dilakukan kepada konsumen produk Miniso di Kota Denpasar dengan 114 responden, menggunakan metode purposive sampling. Pengumpulan data dilakukan melalui kuesioner dan dianalisis dengan Path Analysis. Berdasarkan hasil analisis ditemukan bahwa brand image yang didominasi oleh indikator product image berpengaruh positif dan signifikan terhadap word of mouth. Brand Image yang didominasi oleh indikator product image berpengaruh positif dan signifikan terhadap customer satisfaction. Customer satisfaction yang didominasi oleh indikator kualitas produk secara positif dan signifikan memediasi pengaruh Brand Image terhadap Word of mouth. Hal ini mengimplikasikan bahwa Miniso perlu meningkatkan kualitas desain produk yang menarik, memberikan keunggulan-keunggulan dalam fasilitas, kenyamanan dan pelayanan sehingga terciptanya niat beli konsumen yang tinggi.
\end{abstract}

Kata kunci : brand image, customer satisfaction, WOM

\section{ABSTRACT}

WOM is a form of interpersonal communication between consumers about personal experiences with products or companies. Preliminary survey conducted on 20 consumers who have shopped at Miniso, found that 18 consumers had done word of mouth promotions. This research was conducted to consumers of Miniso products in Denpasar with 114 respondents, using purposive sampling method. Data collected through questionnaire and analyzed by Path Analysis. Based on results, brand image that is dominated by product image indicator has positive and significant effect on word of mouth. Brand Image, dominated by product image indicators has positive and significant effect on customer satisfaction. Customer satisfaction that is dominated by positive and significant product quality indicators mediates the effect of Brand Image on WOM. This implies that Miniso needs to improve the quality of attractive product designs, providing excellence in facilities, comfort and service so as to create high consumer purchase intentions.

Keywords: brand image, customer satisfaction, WOM 


\section{PENDAHULUAN}

Kemajuan ekonomi saat ini di beberapa negara di dunia, berpengaruh pada berkembangnya dunia bisnis secara global. Perkembangan bisnis tersebut membuat munculnya beberapa perusahaan baru, salah satunya yaitu perusahaan yang bergerak di industri ritel. Laporan Global Retail Development Index (GRDI) yang menilai kondisi industri ritel di 30 negara berkembang di dunia, bisnis ritel Indonesia mengalami penurunan dimana pada tahun 2016 bisnis ritel Indonesia berada di posisi ke 5 setelah India, Cina, Malaysia, dan Brasil sebagai negara yang memiliki pertumbuhan bisnis ritel terbaik di kawasan Asia (Saraswati \& Rahyuda, 2017). Pada tahun 2017, Indonesia berada di urutan kedelapan setelah India, China, Malaysia, Turkey, Arab, Vietnam, dan Morroco (ATKearney, 2017). Berbeda dengan peritel lokal yang saat ini banyak gulung tikar, peritel besar dari perusahaan asing justru semakin gencar melakukan ekspansi bisnisnya di Indonesia. Berikut merupakan tabel Retail Development Index di Indonesia.

Kemunculan Miniso sudah populer di kalangan fashionista yang merupakan penggemar produk simple namun dapat digunakan dalam berbagai situasi, baik formal maupun non formal. Miniso mempunyai cara yang langka untuk mempertahankan produknya dan mungkin tidak banyak dilakukan oleh setiap desainer, yaitu dengan memperbaharui produk setiap seminggu sekali, menawarkan produk dengan harga yang rendah dan menargetkan rantai konsumen yang memiliki kecerdasan dalam memilih produk.

Tabel 1.

Volume Penjualan Produk MinisoTahun 2015 - 2017

\begin{tabular}{ll}
\hline Year & Sales Volume \\
\hline 2015 & USD 750 million \\
2016 & USD 1.5 billion \\
2017 & USD 1.8 billion \\
\hline
\end{tabular}

Sumber: Data Diolah, 2019

Tabel 1. menunjukkan volume penjualan Miniso secara global terus mengalami peningkatan dengan volume penjualan mencapai USD 750 juta pada tahun 2015 dan mencapai USD 1,5 miliar pada tahun 2016, sedangkan pada tahun 2017, penjualannya lebih besar yaitu USD 1,8 milyar. Miniso sudah memiliki lebih dari 3.500 gerai dalam 79 negara dan wilayah, sampai tahun 2018 dengan jumlah karyawan lebih dari 30.000 karyawan di seluruh dunia. Miniso juga memiliki target perencanaan strategis dengan membuka 10.000 gerai di 100 negara dengan volume penjualan USD 100 miliar. Produk Miniso yang sudah terdapat di marketplace online akan terus meningkat jumlahnya. Dedikasi utama sebagai merek yang "menghormati konsumen", miniso terus berusaha menyediakan produk yang berkualitas, harga kompetitif dan inovatif untuk konsumen.

Tabel 2. menunjukkan bahwa gerai Miniso tersebar di tiga Kabupaten/Kota di Bali, dengan jumlah gerai paling banyak terdapat di Kabupaten Badung yaitu Miniso Ruko Kuta, Miniso Nusa Dua, Miniso Beachwalk, Miniso Kuta Square dan Miniso Discovery Mall, sedangkan gerai paling sedikit terdapat di Kabupaten 
Gianyar yaitu Miniso Ubud. Pada Kota Denpasar terdapat dua gerai yaitu Miniso Plaza Renon dan Miniso Level21 Mall.

Tabel 2.

Jumlah Gerai Miniso di Bali sampai tahun 2019

\begin{tabular}{ll}
\hline Kabupaten & Jumlah \\
\hline Kota Denpasar & 2 gerai \\
Kabupaten Badung & 5 gerai \\
Kabupaten Gianyar & 1 gerai \\
Total & 8 gerai \\
\hline
\end{tabular}

Sumber: Data Diolah, 2019

Tabel 3.

Prasurvei terhadap konsumen Miniso di Kota Denpasar

\begin{tabular}{|c|c|c|c|}
\hline Keterangan & Ya & Tidak & Total \\
\hline $\begin{array}{l}\text { Perusahaan Miniso memiliki } \\
\text { Reputasi }\end{array}$ & 12 & 3 & 20 \\
\hline $\begin{array}{l}\text { Merasa Puas terhadap produk } \\
\text { Miniso }\end{array}$ & 15 & 5 & 20 \\
\hline Pernah merekomendasikan produk Miniso & 18 & 2 & 20 \\
\hline
\end{tabular}

Sumber: Data Diolah, 2019

Survei pendahuluan yang dilakukan terhadap 20 orang konsumen di Kota Denpasar yang pernah berbelanja di Miniso, diperoleh hasil bahwa 18 konsumen pernah melakukan promosi word of mouth kepada orang sekitar mereka. Hal ini mengindikasikan bahwa perilaku penyebaran word of mouth kerap terjadi setelah konsumen melakukan pembelian di Miniso sehingga menarik untuk dilakukan penelitian terhadap perilaku word of mouth konsumen Miniso di Kota Denpasar.

Di "era globalisasi seperti sekarang ini, informasi mengenai sebuah produk sangat mudah didapatkan, misalnya dari media cetak, media elektronik dan tentunya internet. Semua perusahaan baik berskala besar ataupun kecil berlombalomba memasarkan produk mereka dengan memasang iklan di berbagai media cetak, radio, televisi, internet, dan sebagainya. Namun, sebenarnya ada sebuah bentuk promosi yang sudah berlangsung sejak lama dan masih tetap berpengaruh besar untuk menarik konsumen sampai saat ini yaitu promosi mulut ke mulut atau word of mouth (WOM).

Brand image memiliki peranan yang utama dalam pengembangan dan kemajuan suatu merek yang meliputi nama baik dan kepercayaan merek yang kemudian menjadi petunjuk utama bagi konsumen untuk mencoba atau menggunakan suatu produk barang atau jasa. Brand image positif mampu memberikan anggapan konsumen terhadap merek dan memiliki kemungkinan untuk melakukan pembelian (Hakim et al., 2017). Brand image yang baik akan berdampak positif bagi perusahaan karena mampu memberikan kepuasan atau satisfaction kepada konsumennya, sehingga dapat meningkatkan daya tarik konsumen untuk menggunakan suatu produk (Aristyowati et al., 2015) Pada umumnya harapan dari pelanggan merupakan perkiraan atau keyakinan pelanggan 
tentang apa yang diterimanya bila mereka membeli atau mengkonsumsi suatu produk. Kepuasan ini mendatangkan keuntungan karena bisa mendapatkan pelanggan baru lima kali lebih tinggi daripada mempertahankan yang sudah ada.

Menurut Irawati \& Syahrial (2015), "kepuasan pelanggan menjadi faktor utama dan tujuan yang akan dicapai perusahaan untuk mempertahankan kelangsungan hidup perusahaan dalam pasar bisnis dan mampu meningkatkan keunggulan dalam persaingan". Kepuasan pelanggan dipengaruhi oleh persepsi kualitas jasa, kualitas produk, harga dan faktor-faktor yang bersifat pribadi serta yang bersifat situasi sesaat (Atmawati \& Wahyuddin, 2018).

Berdasarkan reaserch gap antara variabel brand image dan WOM, maka diperlukan variabel pemediasi customer satisfaction. Beberapa alasan memasukkan variabel pemediasi customer satisfaction adalah sebagai berikut. 1) Brand imagemampu meningkatkan WOM. Dapat dibuktikan melalui penelitian yang dilakukan oleh Hasyim et al. (2017) yang menyatakan bahwa hubungan brand image dengan WOM berpengaruh positif dan signifikan.Hasil yang sama juga dibuktikan melalui penelitian Hakim et al. (2017) dan Hudson et al. (2015). Namun, penelitian yang dilakukan oleh Satria \& Hidayat (2018) menyatakan bahwa hubungan brand image dengan WOM berpengaruh positif tetapi tidak signifikan. 2) Brand image yang meningkat mampu meningkatkan customer satisfaction sehingga dapat menciptakan WOM yang baik. 3) Customer satisfaction mampu meningkatkan WOM yang dapat dibuktikan melalui penelitian yang dilakukan oleh Blasco et al. (2017) yang menyatakan bahwa adanya pengaruh positif dan signifikan antara customer satisfaction dengan WOM dalam bisnis ritel di Spanyol (Blasco et al., 2017).

Kepuasan telah muncul sebagai aspek utama penggerak loyalitas; jika pelanggan puas, ada lebih banyak kemungkinan bagi klien untuk memiliki persepsi positif terhadap sebuah perusahaan, menunjukkan loyalitas kepada perusahaan, dan akan secara positif menyebarkan WOM (García-Fernández et al., 2018). Demikian pula, kepuasan pelanggan secara luas dianggap sebagai elemen penting dari banyak niat dan perilaku yang menguntungkan terkait dengan peningkatan loyalitas pelanggan dan keuntungan, pengeluaran operasi yang lebih rendah, dan keberhasilan bisnis yang tinggi, sehingga menjadikannya titik fokus operasi bisnis (Ratanavilaikul, 2018). Salah satu fokus utama perusahaan dalam memuaskan konsumen adalah dengan meningkatkan brand image positif secara berkelanjutan. Brand image adalah sebuah asumsi atau pendapat tentang merek dalam pikiran pelanggan yang harus dipertahankan. Dalam pasar bisnis, brand image sangat berperan penting terutama ketika perusahaan sulit melakukan diferensiasi bentuk fisik produknya.

Kepuasan telah muncul sebagai aspek utama penggerak loyalitas; jika pelanggan puas ada lebih banyak kemungkinan bagi klien untuk memiliki persepsi positif terhadap sebuah perusahaan, menunjukkan loyalitas kepada perusahaan, dan akan secara positif menyebarkan WOM (García-Fernández et al., 2018) Demikian pula, kepuasan pelanggan secara luas dianggap sebagai elemen penting dari banyak niat dan perilaku yang menguntungkan terkait dengan peningkatan loyalitas pelanggan dan keuntungan, pengeluaran operasi yang lebih rendah, dan 
keberhasilan bisnis yang tinggi, sehingga menjadikannya titik fokus operasi bisnis (Ratanavilaikul, 2018).

Kota Denpasar adalah kota yang memiliki laju pertumbuhan ekonomi yang tergolong baik pada tahun 2017 sebesar 6.5 sehingga gaya hidup masyarakatnya cenderung konsumtif tak terkecuali dalam pembelian di gerai Miniso. Maka dari itu, penelitian ini bertujuan untuk mengetahui bagaimana sebuah merek ritel menciptakan brand image yang baik sehingga konsumen melakukan promosi word of mouth yang dimediasi oleh customer satisfaction sehingga berdampak pada profitabilitas perusahaan Miniso.

Berdasarkan uraian tersebut, maka yang menjadi tujuan dari penelitian ini adalah menjelaskan pengaruh brand image terhadap word of mouth konsumen Miniso di Kota Denpasar, menjelaskan pengaruh brand image terhadap customer satisfaction konsumen Miniso di Kota Denpasar, menjelaskan pengaruh customer satisfaction terhadap word of mouth konsumen Miniso di Kota Denpasar dan menjelaskan pengaruh brand image terhadap word of mouth yang dimediasi oleh customer satisfaction konsumen Miniso di Kota Denpasar.

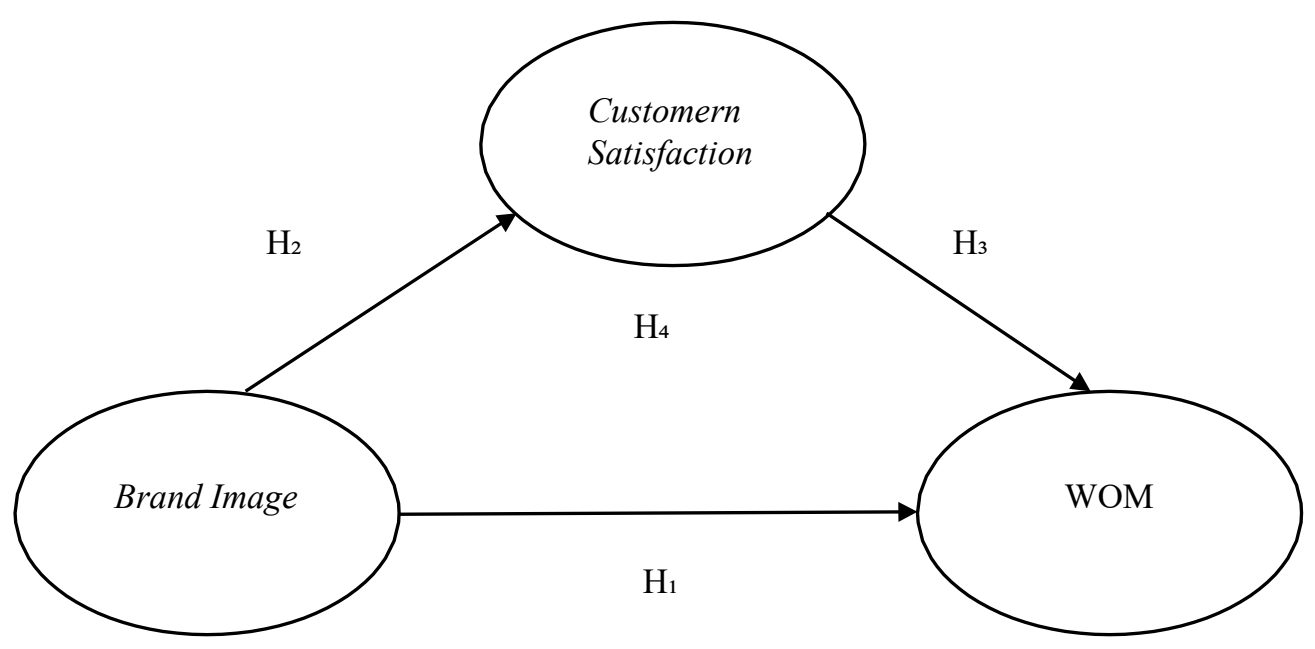

Gambar 1. Kerangka Konseptual

Brand image dan WOM adalah dua hal yang saling terikat dimana brand image yang dianggap baik oleh konsumen dapat menimbulkan perilaku penyebaran WOM positif (Klein et al., 2016). Penelitian yang dilakukan oleh Hasyim et al. (2017) terhadap pembeli Handphone Samsung Galaxy di Fakultas Ilmu Administreasi Universitas Brawijaya, Hakim et al. (2017) terhadap konsumen di rumah makan menyatakan hubungan brand image dan WOM berpengaruh positif dan signifikan. Berbeda dengan penelitian yang dilakukan oleh Satria \& Hidayat (2018) terhadap sekolah vokasi di Indonesia menyatakan hubungan brand image dan WOM berpengaruh positif tetapi tidak signifikan. Berdasarkan hasil penelitian sebelumnya, maka dapat disusun hipotesis sebagai berikut.

$\mathrm{H}_{1}$ : Brand image berpengaruh positif dan signifikan terhadap WOM

Brand image adalah elemen penting untuk mencapai customer satisfaction karena brand image dapat mempengaruhi keputusan dan perilaku pembelian (Lahap et al., 2016). Penelitian yang dilakukan oleh Behboudi \& Hosseini (2017) 
pada sektor kesehatan, Pusparani \& Rastini (2016) dalam penjualan kamera Canon Digital Single Lens Reflex (DSLR) di Kota Denpasar, membuktikan adanya pengaruh yang positif dan signifikan antara brand image dan customer satisfaction. Berbeda dengan penelitian yang dilakukan oleh Haryono \& Octavia (2017) menunjukan bahwa brand image hanya berpengaruh sedikit terhadap customer satisfaction yaitu sebesar $6,3 \%$ dibandingkan dengan mutu layanan sebesar $46 \%$ pada PT. Nusantara Jaya Sentosa. Penelitian Kaihatu (2015) menyatakan bahwa brand image berpengaruh positif tetapi tidak signifikan terhadap customer satisfaction dalam studi kasus konsumen rumah sakit swasta di Surabaya. Berdasarkan dari hasil penelitian sebelumnya, maka dapat disusun hipotesis sebagai berikut.

$\mathrm{H}_{2}$ : Brand image berpengaruh positif dan signifikan terhadap customer satisfaction

Hubungan antara customer satisfaction dan WOM dapat diinterpretasikan dalam bentuk $U$ terbalik sehingga konsumen yang paling puas dan paling tidak puas akan memberikan WOM paling banyak (Velazquez et al., 2017). Penelitian yang dilakukan oleh Blasco et al. (2017) dalam bisnis ritel di Spanyol menyatakan adanya pengaruh positif dan signifikan antara customer satisfaction dan WOM. Berbeda halnya dengan penelitian yang dilakukan oleh Akbari et al. (2015) terhadap brand Adidas, Loureiro et al. (2017) terhadap online retail brand, Cavallero et al. (2018) terhadap website fashion serta Sivadas \& Paul (2017) terhadap penyedia layanan telepon, yang menyatakan bahwa brand image berpengaruh positif tetapi tidak signifikan terhadap WOM. Berdasarkan dari hasil penelitian sebelumnya, maka dapat disusun hipotesis sebagai berikut.

$\mathrm{H}_{3}$ : Customer satisfaction berpengaruh positif dansignifikan terhadap WOM

Dalam penelitian Hamza \& Rahul (2017) dinyatakan bahwa brand image tidak berpengaruh secara langsung terhadap WOM tetapi dimediasi oleh customer satisfaction untuk menyebabkan terjadinya WOM positif secara signifikan terhadap konsumen produk fashion di India. Penelitian lainnya yang menunjukkan hubungan serupa antara lain Wirawan \& Wibawa (2017) terhadap Krisna Oleh-Oleh Bali, Shandra \& Murwatiningsih (2016) terhadap konsumen jasa transportasi New Atlas di Kota Semarang. Berdasarkan dari hasil penelitian sebelumnya, maka dapat disusun hipotesissebagai berikut.

$\mathrm{H}_{4}$ : Customer satisfaction memediasi pengaruh brand image terhadap WOM

\section{METODE PENELITIAN}

Desain penelitian yang digunakan dalam penelitian ini adalah asosiatif karena menjelaskan pengaruh antara variabel satu terhadap variabel lainnya. Penelitian ini dilakukan di Kota Denpasar. Kota Denpasar dijadikan sebagai lokasi penelitian dengan pertimbangan Kota Denpasar merupakan ibukota Provinsi Bali dengan tingkat perekonomian yang cukup tinggi sehingga mempengaruhi gaya hidup berbelanja di toko merek Miniso.

Subjek penelitian adalah responden atau pihak-pihak yang dijadikan sampel dalam sebuah penelitian. Subjek dalam penelitian ini adalah masyarakat secara umum yang telah membeli produk Miniso di Kota Denpasar. Objek penelitian 
adalah konsumen variabel atau hal yang menjadi titik perhatian dalam sebuah penelitian.

Variabel bebas dalam penelitian ini adalah brand image yang disimbolkan dengan (X). Variabel mediasi dalam penelitian ini adalah customer satisfaction yang disimbolkan dengan (M).Variabel terikat dalam penelitian ini adalah word of mouth yang disimbolkan dengan (Y).Data kualitatif dalam penelitian ini adalah informasi mengenai spesifikasi yang dimiliki oleh produk Miniso. Data kuantitatif adalah data yang disajikan dalam bentuk angka-angka bukan dalam bentuk katakata. Data kuantitatif dalam penelitian ini adalah tanggapan responden dari hasil kuisioner.

Populasi dalam penelitian ini adalah konsumen produk Miniso. Sampel dalam penelitian ini adalah konsumen yang pernah melakukan pembelian terhadap produk Miniso. Teknik penentuan sampel yang digunakan pada penelitian ini adalah non probability sampling dengan metode purposive sampling, yaitu sampel ditentukan dengan pertimbangan tertentu. Kriteria sampel dalam penelitian ini sebagai berikut: Berdomisili di Kota Denpasar. Pertimbangan pemilihan Kota Denpasarkarena penelitian ini dilakukan pada masyarakat Kota Denpasar sehingga data akan lebih valid jika responden berdomisili di Kota Denpasar, Pendidikan terakhir minimal SMA/SMK sederajat. Pertimbangan ini digunakan dengan alasan seseorang dengan jenjang pendidikan minimal SMA/SMK sederajat dapat memahami isi kuesioner dan Responden yang pernah melakukan pembelian terhadap produk Miniso minimal sebanyak dua kali.Penelitian ini menggunakan 19 indikator sehingga dengan menggunakan estimasi berdasarkan jumlah parameter diperoleh ukuran sampel sebesar 100-200 responden. Jumlah dari sampel responden yang akan diuji di dapat dari hasil perhitungan sebagai berikut : Jumlah responden $=19$ indikator $\mathrm{x} 6=114$ responden.

Metode yang digunakan untuk mengumpulkan data adalah dengan menyebarkan kuisioner dengan format berupa pernyataan. Isi kuisionerdifokuskan pada faktor-faktor yang mempengaruhi word of mouth yaitu brand image dan customer satisfaction. Hasil dari masing-masing bagian akan menunjukkan pengaruh faktor-faktor tersebut terhadap terciptanya word of mouth untuk membeli kembali produk Miniso. Variabel di dalam kuisioner menggunakan skala Likert, yaitu dengan menjabarkan variabel yang akan diukur menjadi indikator variabel.

\section{HASIL DAN PEMBAHASAN}

Miniso merupakan sebuah merek yang berbasis di Jepang, didirikan bersama oleh desaner Jepang Mr. Miyake Junya dan pengusaha muda Tiongkok Mr. Ye Guofu di Tokyo. Berpegang teguh pada filosofi hidup "simplicity, nature and good quality" dan proposisi merek "back to nature", Miniso berfokus pada persediaan kehidupan dengan keindahan estetika. Dengan nilai-nilai inti dari desain produk yang sangat baik, kinerja biaya tinggi dan pengalaman berbelanja yang nyaman. Miniso mendapatkan popularitas di kalangan konsumen, yang menentukan tren konsumsi pribadi di pasar rumah tangga. 
Tabel 4.

Karakteristik Responden Berdasarkan Usia pada Konsumen Produk Miniso di Kota Denpasar

\begin{tabular}{cccc}
\hline No & Usia & Jumlah (orang) & Presentase (\%) \\
\hline 1 & $16-20$ Tahun & 33 & 28,95 \\
2 & $21-25$ Tahun & 41 & 35,96 \\
3 & $26-30$ Tahun & 25 & 21,93 \\
4 & $31-35$ Tahun & 12 & 10,53 \\
5 & $36-40$ Tahun & 3 & 2,63 \\
\hline & Total & $\mathbf{1 1 4}$ & $\mathbf{1 0 0}$ \\
\hline
\end{tabular}

Sumber: Data Primer (data diolah), 2019

Dari data yang disajikan pada Tabel 4 menunjukkan bahwa produk yang ditawarkan Miniso lebih diminati oleh konsumen usia muda. Hal tersebut dapat diketahui dari jumlah responden terbanyak yang berusia antara 21 - 25 tahun dengan persentase sebesar 35,96 persen. Kelompok usia terbanyak kedua yaitu antara usia 16 - 20 tahun dengan persentase sebesar 28,95 persen. Sedangkan untuk kelompok usia terendah yaitu pada usia 36 - 40 tahun dengan persentase 2,63 persen

Tabel 5.

Karakteristik Responden Berdasarkan Jenis Kelamin pada Konsumen Produk Miniso di Kota Denpasar

\begin{tabular}{cccc}
\hline No & Jenis Kelamin & Jumlah (orang) & Presentase (\%) \\
\hline 1 & Laki - Laki & 28 & 24,56 \\
2 & Perempuan & 86 & 75,44 \\
\hline & Total & $\mathbf{1 1 4}$ & $\mathbf{1 0 0}$ \\
\hline
\end{tabular}

Sumber: Data Primer (data diolah), 2019

Dari data yang disajikan pada Tabel 5. dapat diketahui bahwa sebagian besar responden adalah perempuan sebanyak 86 orang dengan persentase 75,44 persen. Sedangkan responden laki-laki hanya sebanyak 28 orang dengan persentase 24,56 persen. Hal ini dikarenakan produk yang ditawarkan oleh Miniso sebagian besar berupa produk keperluan perempuan.

Tabel 6.

Karakteristik Responden Berdasarkan Pendidikan Terakhir pada Konsumen Produk Miniso di Kota Denpasar

\begin{tabular}{cccc}
\hline No & Pendidikan Terakhir & Jumlah (orang) & Presentase (\%) \\
\hline 1 & SMA/Sederajat & 37 & 33,33 \\
2 & Diploma & 26 & 22,81 \\
3 & S1 & 32 & 28,07 \\
4 & S2 & 15 & 13,16 \\
5 & S3 & 3 & 2,63 \\
\hline & Total & $\mathbf{1 1 4}$ & $\mathbf{1 0 0}$ \\
\hline
\end{tabular}

Sumber: Data Primer (data diolah), 2019 
Dari data yang disajikan pada Tabel 6 dapat diketahui bahwa responden terbanyak mengenyam pendidikan terakhir SMA/Sederajat yaitu sebanyak 37 orang dengan persentase 33,33 persen. Kelompok responden terbanyak kedua yaitu yang mengenyam pendidikan terakhir S1 sebanyak 32 orang dengan persentase 28,07 persen. Kelompok responden terendah yaitu yang mengenyam pendidikan terakhir S3 sebanyak 3 orang dengan persentase 2,63 persen.

Tabel 7.

Karakteristik Responden Berdasarkan Pekerjaan pada Konsumen Produk Miniso di Kota Denpasar

\begin{tabular}{rccc}
\hline No & Jabatan & Jumlah (orang) & Presentase (\%) \\
\hline 1 & Pelajar/Mahasiswa & 47 & 41,23 \\
2 & Karyawan Swasta & 23 & 20,18 \\
3 & PNS & 19 & 16,67 \\
4 & Pengusaha & 11 & 9,65 \\
5 & Lain-lain & 14 & 12,28 \\
\hline & Total & $\mathbf{1 1 4}$ & $\mathbf{1 0 0}$ \\
\hline
\end{tabular}

Sumber: Data Primer (data diolah), 2019

Dari data yang disajikan pada Tabel 7. dapat diketahui bahwa responden lebih banyak berasal dari kalangan pelajar/mahasiswa yaitu sebanyak 47 orang dari 114 responden dengan persentase sebesar 41,23 persen.

Tabel 8.

Hasil Uji Reliabilitas

\begin{tabular}{ccc}
\hline No. & Variabel & Cronbach's Alpha \\
\hline 1 & Corporate Image $\left(\mathrm{X}_{1}\right)$ & 0,645 \\
2 & Product Image $\left(\mathrm{X}_{2}\right)$ & 0,827 \\
3 & User Image (X3) & 0,719 \\
4 & Brand Image (X) & 0,911 \\
5 & Kualitas Produk (M1) & 0,821 \\
6 & Emosional (M2) & 0,758 \\
7 & Harga (M3) & 0,841 \\
8 & Customer Satisfaction (M) & 0,936 \\
9 & WOM (Y) & 0,772 \\
\hline Sumber: Data Primer (data diolah), 2019
\end{tabular}

Seluruh instrumen penelitian memiliki koefisien Cronbach's Alpha lebih dari 0,60 , sehingga seluruh variabel telah memenuhi syarat reliabilitas atau kehandalan sehingga dapat digunakan untuk melakukan penelitian.

Hasil uji validitas menunjukkan bahwa seluruh instrumen penelitian yang digunakan memiliki nilai koefisien korelasi dengan skor total seluruh item pernyataan lebih besar dari 0,3 . Hal ini menunjukkan bahwa butir-butir pernyataan dalam instrumen penelitian tersebut valid dan layak digunakan sebagai instrument penelitian. 
Tabel 9.

Hasil Uji Validitas

\begin{tabular}{ccr}
\hline Variabel & Indikator & Koefisien Korelasi \\
\hline & X1.1 & 0,829 \\
X1.2 & X1 & 0,829 \\
Brand Image (X) & X2.1 & 0,789 \\
& X2.2 & 0,567 \\
& X2.3 & 0,820 \\
X2.4 & 0,865 \\
& X2 & 0,884 \\
& X3.1 & 0,914 \\
X3.2 & 0,916 \\
& X3 & 0,858 \\
& M1.1 & 0,923 \\
& M1.2 & 0,843 \\
M1.3 & 0,930 \\
Customer Satisfaction (M) & M1 & 0,839 \\
& M2.1 & 0,969 \\
& M2.2 & 0,897 \\
& M3.1 & 0,897 \\
& M3.2 & 0,938 \\
& M3.3 & 0,825 \\
& M3 & 0,906 \\
& Y1 & 0,883 \\
& Y2 & 0,931 \\
& Y3 & 0,884 \\
& & 0,706 \\
& & 0,884 \\
& &
\end{tabular}

Sumber: Data Primer (data diolah), 2019

Penilaian responden dengan menggunakan 3 dimensi yaitu corporate image dengan 2 indikator, product image dengan 3 indikator, dan user image dengan 2 indikator, yang kemudian diuraikan ke dalam 8 pernyataan terhadap variabel brand imagepada produk Miniso di Kota Denpasar. rata-rata keseluruhan variabel brand image sebesar 3,99 dan masuk dalam kriteria baik. Variabel brand image yang dibagi ke dalam 3 dimensi yaitu corporate image, product image, dan user image sama-sama memiliki rata-rata keseluruhan yang tergolong baik. Dimana rata-rata keseluruhan dimensi corporate image sebesar 3,94; product image sebesar 4,08; dan user image sebesar 3,96. Pernyataan yang memiliki rata-rata tertinggi yaitu pernyataan nomor 5 yakni sebesar 4,18 dan tergolong baik. "Pernyataan nomor 5 dapat diartikan bahwa responden merasa jika produk Miniso lebih unggul daripada pesaingnya. Pernyataan nomor 1 yang memiliki rata-rata terendah sebesar 3,87, namun pernyataan nomor 1 masih masuk dalam kriteria baik. Pernyataan nomor 1 memiliki arti responden merasa jika Perusahaan Miniso memiliki reputasi. Pernyataan dengan rata-rata terendah selanjutnya adalah pernyataan nomor 8 yakni 
sebesar 3,89 dan masih tergolong baik. Pernyataan nomor 8 memiliki arti responden merasa jika pemakaian produk Miniso dapat menunjukkan kelas sosial responden.

Penilaian responden dengan menggunakan 3 dimensi yaitu kualitas produk dengan 3 indikator, emosional dengan 2 indikator, dan harga dengan 3 indikator yang diuraikan ke dalam 8 pernyataan terhadap variabel customer satisfaction pada konsumen produk Miniso di Kota Denpasar. Customer satisfaction pada produk Miniso di Kota Denpasar secara keseluruhan responden merasa puas, hal ini dapat dilihat dari keseluruhan rata-rata nilai variabel customer satisfaction yaitu sebesar 3,92. Variabel customer satisfaction yang dibagi ke dalam 3 dimensi yaitu kualitas produk, emosional, dan harga sama-sama memiliki rata-rata keseluruhan yang masuk dalam kriteria puas. Dimana rata-rata keseluruhan dimensi kualitas produk sebesar 4,01; emosional sebesar3,80; dan harga sebesar 3,96. Pernyataan yang memiliki rata-rata tertinggi yaitu pernyataan nomor 1 dan 3 yang sama-sama memiliki rata-rata sebesar 4,04 dan tergolong puas. Pernyataan nomor 1 dapat diartikan bahwa responden merasa puas dengan desain dan penampilan produk Miniso menarik. Pernyataan nomor 3 dapat diartikan bahwa responden merasa puas dengan Produk Miniso yang nyaman saat digunakan.

Pernyataan yang memiliki nilai rata-rata terendah adalah pernyataannomor 5 yang memiliki rata-rata terendah sebesar 3,79 , namun pernyataan nomor 5 masih masuk dalam kriteria puas. Pernyataan nomor 5 memiliki arti responden merasa bangga saat menggunakan produk Miniso. Pernyataan dengan rata-rata terendah selanjutnya adalah pernyataan nomor 4 yakni sebesar 3,82 dan masih tergolong baik dan tidak jauh berbeda dengan nilai rata-rata lainnya. Pernyataan nomor 4 memiliki arti responden merasa merasa puas terhadap produk Miniso di Kota Denpasar.

Penilaian responden dengan menggunakan 3 indikator yang diuraikan ke dalam 3 pernyataan terhadap variabel word of mouth (WOM) pada produk Miniso di Kota Denpasar. 3 pernyataan mengenai word of mouth memiliki nilai rata-rata sebesar 3,92 yang berarti bahwa WOM pada konsumen produk Miniso di Kota Denpasar tergolong baik. Nilai rata- rata tertinggi dimiliki oleh pernyataan nomor 3 yaitu sebesar 3,96 yang termasuk kategori baik. Pernyataan nomor 1 memiliki nilai rata-rata tertinggi kedua dengan nilai rata-rata sebesar 3,94. Pernyataan nomor 2 memiliki rata-rata terendah, namun meski memiliki rata-rata terendah, pernyataan nomor dua memiliki nilai rata-rata tidak jauh berbeda dengan pernyataan lainnya yaitu sebesar 3,84 dan masih tergolong baik.

Tabel 10.

Hasil Uji Normalitas Persamaan Regresi 1

\begin{tabular}{cc}
\hline & Unstandardized Residual \\
\hline $\mathrm{N}$ & 114 \\
Kolmogorov Smirnov & 0,958 \\
Asymp. Sig. (2-tailed) & 0,318 \\
\hline
\end{tabular}

Sumber: Data Primer (data diolah), 2019

Nilai Kolmogorov Smirnov $(K-S)$ sebesar 0,958 sedangkan nilai Asymp. Sig. (2-tailed) sebesar 0,318. Hasil tersebut mengindikasikan bahwa model persamaaan 
regresi tersebut berdistribusi normal karena nilai Asymp. Sig. (2-tailed) sebesar 0,318 dimana lebih besar dari nilai alpha yaitu 0,05 .

Tabel 11.

Hasil Uji Normalitas Persamaan Regresi 2

\begin{tabular}{cc}
\hline & Unstandardized Residual \\
\hline $\mathrm{N}$ & 114 \\
Kolmogorov Smirnov & 0,923 \\
Asymp. Sig. (2-tailed) & 0,362 \\
\hline
\end{tabular}

Sumber: Data Primer (data diolah), 2019

Nilai Kolmogorov Smirnov $(K-S)$ sebesar 0,923 sedangkan nilai Asymp. Sig. (2-tailed) sebesar 0,362. Hasil tersebut mengindikasikan bahwa model persamaaan regresi tersebut berdistribusi normal karena nilai Asymp. Sig. (2-tailed) sebesar 0,362 dimana lebih besar dari nilai alpha yaitu 0,05 .

Tabel 12.

Hasil Uji Multikolinieritas Persamaan Regresi 1

\begin{tabular}{rcr}
\hline Variabel & Tolerance & VIF \\
\hline Brand Image & 1,000 & 1,000
\end{tabular}

Sumber: Data Primer (data diolah), 2019

Berdasarkan nilai tolerance dan VIF dari varibel brand image. Nilai tersebut menunjukkan bahwa nilai tolerance untuk setiap variabel lebih besar dari 10 persen dan nilai VIF lebih kecil dari 10 yang berarti model persamaan regresi 1 bebas dari multikolinieritas.

Tabel 13.

Hasil Uji Multikolinieritas Persamaan Regresi 2

\begin{tabular}{rcr}
\hline Variabel & Tolerance & VIF \\
\hline Service Quality & 0,487 & 2,054 \\
Customer Satisfaction & 0,487 & 2,054 \\
\hline
\end{tabular}

Sumber: Data Primer (data diolah), 2019

Berdasarkan nilai tolerance dan VIF dari varibel brand image dan customer satisfaction. Nilai tersebut menunjukkan bahwa nilai tolerance untuk setiap variabel lebih besar dari 10 persen dan nilai VIF lebih kecil dari 10 yang berarti model persamaan regresi 2 bebas dari multikolinieritas.

Tabel 14.

Hasil Uji Heteroskedastisitas Persamaan Regresi 1

\begin{tabular}{llllll}
\hline Model & $\begin{array}{c}\text { Unstandardized } \\
\text { Coefficients }\end{array}$ & $\begin{array}{l}\text { Standardized } \\
\text { Coefficients }\end{array}$ & T & Sig. \\
& B & Std. Error & Beta & & \\
\hline (Constant) & .188 & .179 & & 1.049 & .297 \\
Brand Image (X) & .026 & .045 & .056 & .592 & .555 \\
\hline
\end{tabular}

Sumber: Data Primer (data diolah), 2019 
Nilai signifikansi dari variabel brand imagesebesar 0,555 lebih besar dari 0,05 yang berarti tidak terdapat pengaruh antara variabel bebas terhadap absolut residual, dengan demikian, model yang dibuat tidak mengandung gejala heteroskedastisitas.

Tabel 15.

Hasil Uji Heteroskedastisitas Persamaan Regresi 2

\begin{tabular}{llllll}
\hline Model & $\begin{array}{c}\text { Unstandardized } \\
\text { Coefficients }\end{array}$ & $\begin{array}{l}\text { Standardized } \\
\text { Coefficients }\end{array}$ & T & Sig. \\
& B & Std. Error & Beta & & \\
\hline (Constant) & .253 & .205 & & 1.233 & .220 \\
Brand Image (X) & .093 & .069 & .182 & 1.346 & .181 \\
Customer Satisfaction (M) -.081 & .067 & -.162 & -1.198 & .233 \\
\hline
\end{tabular}

Sumber: Data Primer (data diolah), 2019

Nilai signifikansi dari variabel brand image dan customer satisfaction masing-masing sebesar 0,181 dan 0,233 . Nilai- nilai tersebut lebih besar dari 0,05 yang berarti tidak terdapat pengaruh antara variabel bebas terhadap absolut residual, dengan demikian model yang dibuat tidak mengandung gejala heteroskedastisitas.

Tabel 16.

Hasil Analisis Jalur Persamaan Regresi 1

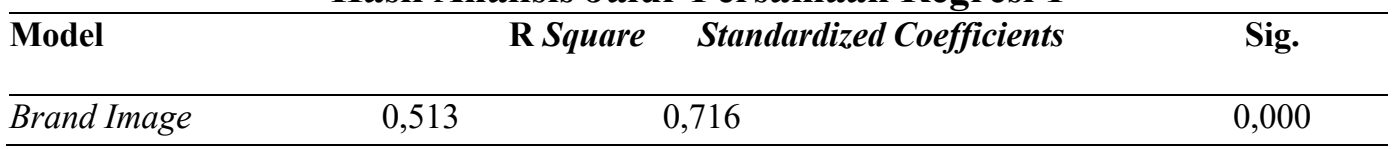

Sumber: Data Primer (data diolah), 2019

Nilai $\beta 1$ adalah sebesar 0,716 memiliki arti brand image berpengaruhpositif terhadap customer satisfaction, dengan kata lain jika faktor brand image meningkat maka customer satisfaction meningkat.

Tabel 17.

Hasil Analisis Jalur Persamaan Regresi 2

\begin{tabular}{lccr}
\hline & & \multicolumn{3}{c}{ Standardized Coefficients } \\
\cline { 3 - 4 } \multicolumn{1}{c}{ Model } & R Square & Beta & Sig. \\
\hline Brand Image & 0,610 & 0,410 & 0,000 \\
Customer Satisfaction & & 0,433 & 0,000 \\
\hline
\end{tabular}

Sumber: Data Primer (data diolah), 2019

Nilai $\beta 2$ adalah sebesar 0,410 memiliki arti brand image berpengaruh positif terhadap word of mouth, dengan kata lain jika faktor brand image meningkatmaka word of mouth meningkat. Nilai $\beta 3$ adalah sebesar 0,433 memiliki arti customer satisfaction berpengaruh positif terhadap word of mouth, dengan kata lain jika faktor customer satisfaction meningkat maka word of mouth meningkat.

Nilai determinasi total sebesar 0,537 mempunyai arti bahwa sebesar 53,7\% variasi word of mouth dipengaruhi oleh variasi brand image dan customer 
satisfaction, sedangkan sisanya sebesar $46,3 \%$ dijelaskan oleh faktor-faktor lain yang tidak dimasukkan ke dalam model.

Berdasarkan hasil analisis pengaruh brand image terhadap word of mouth, diperoleh hasil nilai koefisien $\beta 2=0,410$ dengan nilai signifikansi sebesar 0,000 . Nilai koefisien $\beta 1>0$ dan nilai signifikansi $<0,05$ mengindikasikan bahwa brand image berpengaruh positif dan signifikan terhadap word of mouth, dengan demikian $\mathrm{H} 1$ diterima dan $\mathrm{H} 0$ ditolak. Berdasarkan hasil analisis pengaruh brand image terhadap customer satisfaction, diperoleh hasil nilai koefisien $\beta 1=0,716$ dengan nilai signifikansi sebesar 0,000 . Nilai koefisien $\beta 2>0$ dan nilai signifikansi $<0,05$ mengindikasikan bahwa brand image berpengaruh positif dan signifikan terhadap customer satisfaction, dengan demikian $\mathrm{H} 1$ diterima dan $\mathrm{H} 0$ ditolak. Berdasarkan hasil analisis pengaruh customer satisfaction terhadap word of mouth, diperoleh hasil nilai koefisien $\beta 3=0,433$ dengan nilai signifikansi sebesar 0,000 . Nilai koefisien $\beta 3>0$ dan nilai signifikansi $<0,05$ mengindikasikan bahwa customer satisfaction berpengaruh positifdan signifikan terhadap word of mouth, dengan demikian $\mathrm{H} 1$ diterimadan $\mathrm{H} 0$ ditolak.

Tabel 18.

Pengaruh Langsung dan Pengaruh Tidak Langsung serta Pengaruh Total

\begin{tabular}{lccc}
\hline \multicolumn{1}{c}{ Pengaruh Variabel } & $\begin{array}{r}\text { Pengaruh } \\
\text { Langsung }\end{array}$ & $\begin{array}{c}\text { Mengaruh Tidak Langsung } \\
\text { Melai Mediasi } \\
(\boldsymbol{\beta 1} \mathbf{x} \boldsymbol{\beta} 3)\end{array}$ & Pengaruh Total \\
\hline $\mathrm{X} \rightarrow \mathrm{M}$ & 0,716 & - & 0,716 \\
$\mathrm{X} \rightarrow \mathrm{Y}$ & 0,410 & 0,310 & 0,720 \\
$\mathrm{M} \rightarrow \mathrm{Y}$ & 0,433 & - & 0,433 \\
\hline
\end{tabular}

Sumber: Data Primer (data diolah), 2019

Brand image memiliki pengaruh langsung terhadap word of mouth dan pengaruh tidak langsung melalui customer satisfaction. Hasil koefisien pengaruh tidak langsung lebih kecil dibandingkan pengaruh langsung $(0,310<0,410)$, sehingga dapat dikatakan bahwa variabel customer satisfaction adalah sebagai variabel mediasi dalam memediasi pengaruh variabel brand image tehadap variabel word of mouth. Berdasarkan perhitungan, didapatkan nilai z hitung sebesar 3,922 yang artinya lebih besar dari nilai $\mathrm{z}$ tabel yaitu $(3,922>1,96)$. Hasil ini memiliki arti bahwa customer satisfaction mampu memediasi secara signifikan pengaruh brand image terhadap word of mouth.

Berdasarkan hasil perhitungan tersebut, dapat disimpulkan bahwa variabel customer satisfaction (M) memediasi secara parsial (partial mediation) pengaruh variabel brand image (X) terhadap word of mouth (Y). Hal ini dikarenakan berdasarkan hasil perhitungan nilai VAF sebesar 100 persen, dimana jika nilai VAF diantara 20 persen hingga 80 persen maka dapat disimpulkan jika peran variabel mediasi sebagai pemediasi parsial.

Hasil ini mengindikasikan bahwa variabel brand image yang didominasi oleh indikator Produk Miniso lebih unggul dibanding pesaingnya berpengaruh positif dan signifikan terhadap WOM. Rangkuman penelitian responden yang disajikan 
dalam deskripsi variabel penelitian menunjukkan penilaian responden terhadap brand image pada Miniso dalam kategori baik. Hal tersebut menunjukkan bahwa memang benar bahwa produk yang dikeluarkan oleh Miniso lebih unggul dibanding pesaing, sehingga niat beli konsumen miniso akan bertambah dan dapat menghasilkan promosi dari mulut ke mulut.

Hasil pengujian menunjukkan bahwa semakin tinggi brand image Miniso di Kota Denpasar maka semakin tinggi tingkat penyebaran WOM positif, juga sebaliknya jika brand image Miniso di Kota Denpasar semakin rendah maka semakin rendah pula tingkat penyebaran WOM positif. Hasil penelitian ini didukung oleh penelitian yang dilakukan Hasyim et al. (2017) menjelaskan bahwa brand image berpengaruh signifikan dan positif terhadap word of mouth. Memiliki image yang positif dan kuat akan lebih mempermudah untuk komunikasi pemasaran agar diterima oleh konsumen. Artinya kesan positif yang diciptakan dalam komunikasi pemasaran tentang suatu merek akan mengakibatkan orang mampu menerima klaim baru terhadap kinerja produk dan akan menerimanya sehingga lebih mudah untuk dipengaruhi membeli produk tersebut. Adapun penelitian Hakim et al. (2017) menyatakan bahwa dengan adanya brand image yang dimiliki oleh perusahaan mampu mempengaruhi konsumen dalam merekomendasikan secara word of mouth kepada calon konsumen.

Indikator corporate image dengan pernyataan "Perusahaan Miniso memiliki reputasi yang baik" memperoleh nilai rata-rata yang paling kecil dibandingkan dengan indikator lainnya. citra merek yang kuat dapat mengembangkan citra perusahaan dengan membawa nama perusahaan serta dapat membantu mengiklankan kualitas dan besarnya perusahaan. Hasil wawancara terhadap beberapa responden menghasilkan pernyataan bahwa pernyataan "Perusahaan Miniso memiliki reputasi yang baik" dapat ditingkatkan apabila konsumen mendapatkan sesuatu yang ingin dicari dalam satu tempat dan mendapatkan produk yang berkualitas, sehingga kebutuhan konsumen akan terpenuhi apabila berbelanja di Miniso. Perusahaan Miniso perlu untuk meningkatkan kualitas desain produk yang lebih menarik agar dapat menarik minat konsumen, selain itu Miniso perlu meningkatkan kenyamanan dan pelayanan sehingga minat beli konsumen akan meningkat.

Hasil ini mengindikasikan bahwa variabel brand image yang didominasi oleh indikator Produk Miniso lebih unggul dari pesaingnya berpengaruh positif dan signifikan terhadap customer satisfaction. Hasil pengujian menunjukkan bahwa semakin tinggi brand image Miniso di Kota Denpasar maka semakin tinggi pula kepuasan para pelanggan, juga sebaliknya jika brand image Miniso di Kota Denpasar semakin rendah maka semakin rendah pula kepuasan pelanggan. Hasil penelitian ini mendukung penelitian yang dilakukan oleh Pusparani \& Rastini (2016) yang menyatakan bahwa semakin tinggi kualitas produk maka konsumen akan merasa puas menggunakan produk tersebut. Apabila perusahaan dapat mendesain produk secara menarik dan memberikan pelayanan terbaik, maka dampaknya adalah konsumen akan merasa puas karena kebutuhan konsumen dapat terpenuhi dengan baik.

Hasil wawancara terhadap beberapa responden menghasilkan pernyataan bahwa pernyataan "Perusahaan Miniso memiliki reputasi yang baik" dapat 
ditingkatkan apabila konsumen mendapatkan sesuatu yang ingin dicari dalam satu tempat dan mendapatkan produk yang berkualitas, sehingga kebutuhan konsumen akan terpenuhi apabila berbelanja di Miniso. Perusahaan Miniso perlu untuk meningkatkan kualitas desain produk yang lebih menarik agar dapat menarik minat konsumen, selain itu Miniso perlu memberikan keunggulan-keunggulan dalam fasilitas, sehingg terciptanya kepuasan konsumen yang berbelanja di Miniso.

Hasil ini mengindikasikan bahwa variable customer satisfaction yang didominasi oleh indikator Mengajak konsumen dalam membeli produk Miniso berpengaruh positif dan signifikan terhadap word of mouth. Rangkuman penelitian responden yang disajikan dalam deskripsi variabel penelitian menunjukkan penilaian responden terhadap word of mouth pada Miniso dalam kategori baik. Hal tersebut menunjukkan bahwa memang benar konsumen Miniso juga mengajak konsumen lain untuk membeli produk Miniso. Akan tetapi indikator dengan pernyataan "Merekomendasikan produk Miniso kepada orang lain memperoleh nilai rata-rata yang paling kecil dibandingkan dengan indikator lainnya.

Hasil pengujian menunjukkan bahwa semakin tinggi kepuasan pelanggan Miniso di Kota Denpasar maka semakin tinggi tingkat penyebaran Miniso positif, juga sebaliknya jika kepuasan pelanggan Miniso di Kota Denpasar semakin rendah maka semakin rendah pula tingkat penyebaran word of mouth positif. Hasil wawancara terhadap beberapa responden menghasilkan pernyataan bahwa pernyataan "Merekomendasikan produk Miniso kepada orang lain" dapat ditingkatkan apabila perusahaan Miniso dapat meningkatkan kualitas produk dan terus memunculkan inovasi baru yang mengikuti perkembangan pasar sehingga konsumen merasa puas dengan produk Miniso dan menjadikan Miniso sebagai pilihan utama untuk berbelanja produk retail.

Hal ini sejalan dengan peneltiian yang dilakukan Hamza \& Rahul (2017) dinyatakan bahwa brand image tidak berpengaruh secara langsung terhadap WOM tetapi dimediasi oleh customer satisfaction untuk menyebabkan terjadinya WOM positif secara signifikan terhadap konsumen produk fashion di India. Penelitian lainnya yang menunjukkan hubungan serupa antara lain Wirawan \& Wibawa (2017) terhadap Krisna Oleh-Oleh Bali, Shandra \& Murwatiningsih (2016) terhadap konsumen jasa transportasi New Atlas di Kota Semarang.

Customer satisfaction mampu menjadi perantara bagi brand image untuk menimbulkan word-of-mouth. Brand Image yang dimediasi customer satisfaction akan berpengaruh lebih besar pada word-of-mouth konsumen di gerai Miniso Denpasar, dibandingkan pengaruh langsung dari Brand Image terhadap word-ofmouth pada Miniso Denpasar. Hasil rangkuman penelitian responden yang disajikan dalam deskripsi variabel penelitian menunjukkan penilaian responden terhadap customer satisfaction pada Miniso dalam kategori baik. Artinya customer satisfaction yang didominasi oleh dimensi kualitas produk khususnya indikator "Produk Miniso nyaman saat digunakan". Hal ini berarti memang benar jika produk Miniso nyaman digunakan sehingga dapat menciptakan kepuasan terhadap konsumen dan secara langsung akan meningkatkan niat beli terhadap produk Miniso.

Hasil wawancara terhadap beberapa responden menghasilkan pernyataan bahwapernyataan "Merasa bangga menggunakan produk Miniso" yang merupakan 
indikator terendah dapat ditingkatkan apabila konsumen mendapatkan pelayanan yang baik dan kemudahan dalam bertransaksi, sehingga perusahaan Miniso seharusnya lebih meningkatkan kinerja pelayanan dengan memberikan pelayanan yang responsive agar dapat memberikan kepuasan kepada konsumen dan dapat direkomendasikan kepada konsumen lainnya.

Berdasarkan penelitian yang telah dilakukan dapat diketahui bahwa secara teoritis, penelitian ini secara keseluruhan mendukung beberapa teori yang telah ada sebelumnya. Penelitian ini diharapkan dapat memberikan kontribusi empiris tentang hubungan antara variabel brand image, customer satisfaction, dan word-ofmouth bagi pengembangan ilmu pemasaran. Hasil penelitian ini diharapkan dapat digunakan untuk memperkaya referensi dan ilmu pengetahuan yang berkaitan dengan variabel brand image, customer satisfaction, dan word-of-mouth. Hasil penelitian ini diharapkan dapat menjadi referensi bagi pihak manajemen Miniso dalam memanfaatkan aspek brand image yang baik bagi konsumen sehingga mampu menciptakan customer satisfaction pada pelanggan yang pada akhirnya menimbulkan word-of-mouth Pada variabel customer satisfaction, pelanggan secara keseluruhan merasa puas dengan proses belanja di Miniso, merasa Miniso sudah memberikan pelayanan yang sesuai dengan harapan konsumen, dan merasa berbelanja di Miniso lebih memuaskan dibandingkan pesaing sehingga menimbulkan word of mouth.

\section{SIMPULAN}

Brand Image yang didominasi oleh indikator product image berpengaruh positif dan signifikan terhadap word of mouth. Hasil ini berarti, semakin baik brand image atau citra merek dalam berbelanja di gerai Miniso Denpasar maka akan wordof mouth akan semakin meningkat di gerai Miniso Denpasar. Brand Image yang didominasi oleh indikator product image berpengaruh positif dan signifikan terhadap customer satisfaction. Hasil ini berarti, semakin baik brand image atau citra merek dalam berbelanja di gerai Miniso Denpasar maka akan semakin meningkatkan customer satisfaction atau kepuasan konsumen yang dirasakan oleh konsumen Miniso tersebut. Customer satisfaction berpengaruh positif dan signifikan terhadap Word-of Mouth. Hasil ini berarti, semakin tinggi customer satisfaction atau kepuasan konsumen yang dirasakan oleh konsumen Miniso akan semakin mendorong timbulnya word-of mouth di gerai Miniso Denpasar. Customer satisfaction yang didominasi oleh indicator kualitas produk secara positif dan signifikan memediasi pengaruh Brand Image terhadap Word of mouth. Hasil ini berarti, kepuasan konsumen mampu memperkuat pengaruh citra mereka terhadap word of mouth konsumen pada gerai Miniso Denpasar.

Perusahaan Miniso dapat menjaga reputasi, apabila manajemen Miniso lebih meningkatkan kualitas desain produk yang lebih menarik, meningkatkan kepercayaan dan keyakinan konsumen kepada Miniso, serta memberikan keunggulan-keunggulan dalam fasilitas, kenyamanan dan pelayanan misalnya dengan selalu mengecek persediaan barang dan memastikan kondisi barang dalam keadaan baik. Perusahaan Miniso dapat meningkatkan rasa bangga konsumen, apabila manajemen Miniso mampu meningkatkan kinerja pelayanannya dengan 
memberikan pelayanan yang responsive misalnya apabila konsumen bertanya mengenai ketersediaan barang atau kelebihan barang, karyawan dengan sigap membantu konsumen, serta keamanan dan kemudahan dalam bertransaksi misalnya dengan menyediakan mesin gesek yang diletakkan disetiap kasir agar konsumen tidak lagi kesusahan untuk menarik uang sebelum melakukan pembayaran. Perusahaan Miniso sebaiknya mampu meningkatkan kualitas produk dan melakukan inovasi pada produk yang mampu memenuhi kebutuhan pengguna Miniso. Pihak Miniso juga perlu untuk menjaga agar kinerja pelayanan Miniso sesuai dengan apa yang dijanjikan dan mampu melebihi harapan konsumen, sehingga konsumen merasa puas berbelanja Miniso dan menjadikan Miniso sebagai pilihan utama ketika berbelanja produk retail.

\section{REFERENSI}

Akbari, M., Salehi, K., \& Samadi, M. (2015). Brand Heritage and WOM: The Mediating Role of Brand Personality, Product Involvement and Customer Satisfaction. Journal of Marketing Management, 3(1), 83-90.

Aristyowati, N., Minarsih, M. M., \& Fathoni, A. (2015). Effect of Quality Products, Brand Image and Price Towards Purchase Decision (Studies in Buyer OBH Combi in Pharmacies in Semarang). Journal of Management, 1(1), 1-15.

Atmawati, R., \& Wahyuddin, M. (2018). Analisis Pengaruh Kualitas Pelayanan Terhadap Kepuasan Konsumen Pada Matahari Departement Store Di Solo Grand Mall. Jurnal Ekonomi Manajemen Sumber Daya, 5(1), 54-61.

Behboudi, L., \& Hosseini, S. H. K. (2017). Brand Trust and Image : Effects on Customer Satisfaction. Journal of Health Care Quality Assurance, 7(7), 580590 .

Blasco, M. F., Velázquez, M. B., \& Gil-Saura, I. (2017). Analyzing Heterogeneity on The Value, Satisfaction, WOM Relationship in Retailing. Management Decision, 55(7), 1558-1577.

Cavallero, L., Loureiro, S. M. C., \& Miranda, F. J. (2018). Fashion Brands on Retail Websites: Customer Performance Expectancy and eWOM. Journal of Retailing and Consumer Services, 41(7), 131-141.

García-Fernández, J., Gálvez-Ruíz, P., Fernández-Gavira, J., Vélez-Colón, L., Pitts, B., \& Bernal-García, A. (2018). The Effects of Service Convenience and Perceived Quality on Perceived Value, Satisfaction and Loyalty in Low- Cost Fitness Centers. Sport Manag, 21(3), 250-262.

Hakim, F. R., Achmad, F. D. H., \& Mukhammad, K. M. (2017). Pengaruh Citra Merek Terhadap WOM Serta Dampaknya Pada Keputusan Pembelian (Survei Pada Konsumen Warung Pring Pethuk di Jalan Cemara Kipas Dalam, Kota 
Batu). Jurnal Administrasi Bisnis, 43(1), 180-186.

Hamza, V. K., \& Rahul, G. (2017). Mediation of Brand Equity on WOM : A Study with Special Reference to Customers of Fashion Products in India. Journal of Business Administration, 10(10), 23-29.

Haryono, N., \& Octavia, H. (2017). Analisis Pengaruh Citra Merek dan Mutu Layanan Terhadap Kepuasan Konsumen Serta Dampaknya Terhadap Loyalitas Konsumen. Jurnal INDEPT, 4(1), 20-27.

Hasyim, M. A., Achmad, F., \& Fanani, D. (2017). Pengaruh Citra Merek Terhadap WOM dan Keputusan Pembelian (Suvei Pada Mahasiswa Fakultas Ilmu Administrasi Universitas Brawijaya). Jurnal Administrasi Bisnis, 43(1), 138156.

Hudson, S., Roth, M. S., Madden, T. J., \& Hudson, R. (2015). The Effects of Social Media on Emotions, Brand Relationship Quality and WOM : An Empirical Study of Music Festival Attendees. Journal of Tourism Management, 47(3), $68-76$.

Irawati, \& Syahrial, H. (2015). Pengaruh Kualitas Produk dan Kualitas Pelayanan Terhadap Kepuasan Pelanggan Pengguna Modem Smartfren Pada Mahasiswa Fakultas Ekonomi Universitas Medan Area. Jurnal Konsep Bisnis Dan Manajemen, 1(2), 17-28.

Kaihatu, T. (2015). Kepuasan Konsumen yang Dipengaruhi oleh Kualitas Layanan dengan Brand Image sebagai Variabel Perantara : Studi Kasus Pada Konsumen Rumah Sakit Swasta di Surabaya. Jurnal Mitra Ekonomi Dan Manajemen Bisnis, 3(2), 200-210.

Klein, J. F., Falk, T., Franz-Rudolf, E., \& Gloukhovtsev, A. (2016). Linking PopUp Brand Stores to Brand Experience and WOM : The Case of Luxury Retail. Journal of Business Research, 69(12), 5761-5767.

Lahap, J., Ramli, N. S., Said, N. M., Radzi, S. M., \& Zain, R. A. (2016). A Study of Brand Image Towards Customer's Satisfaction in The Malaysian Hotel Industry. Social and Behavioral Sciences, 224(10), 149-157.

Loureiro, S. M. C., Gorgus, T., \& Kaufmann, H. R. (2017). Antecedents and Outcomes of Online Brand Engagement: The Role of Brand Love on Enhancing eWOM. Journal Online Information Review, 41(7), 985-1005.

Pusparani, P. A. Y., \& Rastini, N. M. (2016). Pengaruh Kualitas Produk Dan Brand Image Terhadap Kepuasan Konsumen dan Loyalitas Pelanggan Kamera Canon Digital Single Lens Reflex (DSLR) Di Kota Denpasar. E-Jurnal Manajemen Unud, 3(5), 1311-1319. 
Ratanavilaikul, B. (2018). Customer Perceived Value, Satisfaction, \& Behavioral Intentions in The Logistic Industry. AU J. Management, 10(2), 63-71.

Saraswati, A. R., \& Rahyuda, K. (2017). Brand Image Memediasi Kualitas Produk dan Harga dengan Keputusan Pembelian Smartphone Apple di Kota Denpasar. E-Jurnal Manajemen Unud, 6(6), 3252-3282.

Satria, H. W., \& Hidayat, D. P. (2018). Does Brand Love and Brand Image Have A Strong Impact on WOM? (Evidence from The Indonesian Vocational School). Kne Social Sciences, 2(2), 320-346.

Shandra, M. P. K., \& Murwatiningsih. (2016). Kepuasan Konsumen Sebagai Mediasi Pengaruh Kualitas Pelayanan, Brand Image, dan Harga Terhadap Loyalitas Konsumen. Management Analysis Journal, 5(2), 36-43.

Sivadas, E. R., \& Paul, J. (2017). Alternative Measures of Satisfaction and WOM. Journal of Services Marketing, 31(2), 121-129.

Velazquez, B. M., Blasco, M. F., Servera-Frances, D., \& Gil-Saura, I. (2017). Role of Marketing and Technological Innovation on Store Equity, Satisfaction and WOM in Retailing. Journal of Product and Brand Management, 26(6), 650666.

Wirawan, I. W. G. D., \& Wibawa, I. M. A. (2017). Pengaruh Brand Image dan Customer Satisfaction Terhadap WOM di Krisna Oleh-Oleh Khas Bali. EJournal Manajemen Unud, 1(7), 77-89. 